DOI: $10.24193 /$ tras.65E.1

Published First Online: 02/25/2022

\section{PUBLIC ADMINISTRATION \\ DIGITALIZATION AND CORRUPTION \\ IN THE EU MEMBER STATES. \\ A COMPARATIVE AND CORRELATIVE \\ RESEARCH ANALYSIS}

\section{Armenia ANDRONICEANU \\ Irina GEORGESCU \\ Jani KINNUNEN}

\section{Abstract}

Effective digitalization of public administrations and economies requires rethinking of how e-government and digital services with increasing e-participation can support corruption reduction and social development. This paper aims to study the interdependencies and differences between the multidimensional phenomena of administrative corruption and digitalization in the EU member states. The research methods applied are Canonical Correlation Analysis and Principal Component Analysis. Ten relevant variables for 2019 and 2020 were selected and integrated into this research. The research results showed that digitalization significantly improved the quality of public administrations and reduced corruption. The new composite index designed and determined for EU member states showed a vast gap between the Nordic and Eastern European countries.

Our results confirm that the level of e-government was found to be the best predictor of control of corruption and government effectiveness suggesting that digitalized and less corrupt governments also made economies more competitive. The digitization of public administration and services is a strategic objective of EU member states and should become a priority in the new technological era.

Keywords: public administration, digitalization, corruption, e-government, canonical correlation analysis, component analysis, composite index.
Professor, Faculty of Administration and Public Management, Bucharest University of Economic Studies, Bucharest, Romania E-mail: armenia.androniceanu@man.ase.ro ORCID ID: 0000-0001-7072-7019

\section{Irina GEORGESCU}

Associate Professor, Department of Informatics and Economic Cybernetics, Bucharest University of Economic Studies, Bucharest, Romania

E-mail: irina.georgescu@csie.ase.ro

ORCID ID: 0000-0002-0154-6617

\section{Jani KINNUNEN}

Researcher, Department of Information Systems, Åbo Akademi University, Turku, Finland

E-mail: jani.kinnunen@abo.fi

ORCID ID: 0000-0002-0154-6617

\section{Armenia ANDRONICEANU}




\section{Introduction}

Globally, not only the economy but also public administration and society are influenced by technological transformations. Countries that do not prioritize the cross-cutting integration of digital technology at all levels of the economy, public administration, and society will suffer. Beyond efficiency, the digitalization of public services in developed countries in Europe and beyond sends a strong signal at the international, national, and local level on the need for change and digital transformation to move into an era of transparency, quality of public services, and the fight against corruption. The ongoing digital revolution has changed the frame of contemporary economies, modern businesses, and public administration by promoting and implementing new technological solutions for digitalization (Rymarczyk, 2021). The modernization of public administration and services as a result of the integration of information and communication technologies is essential and should become a continuing concern of state governments (Mansell, 2012). In countries where these changes occurred, they have been proven to be an effective way to reduce corruption (Mouna, Nedra and Khaireddine, 2020). The digitalization of public institutions increases the level of efficiency and transparency and should be one of the key pillars of the development of any smart community (Vogelsang, 2010; Șandor, 2018). Through digitalization, the entire activity of public institutions is streamlined on all three levels: internally, intra-institutionally, and externally (Afonasova et al., 2019). Digitalization increases the transparency and accountability to citizens of the authorities (Balzer, Užík and Glova 2020); transparency and openness of public institutions are essential for a democratic society.

Corruption is an obstacle both for economic growth and for good public administration. By transferring resources outside the economic and social system, the efficiency of public spending is significantly affected (Winston, 1998). Although the EU has shown the best performance in the world in reducing corruption during the last years, the corruption costs for the EU economy are estimated at EUR 120 billion per year (European Commission, 2020). Corruption plays a role in discouraging taxpayers from paying taxes (Osipov, Glotov and Karepova, 2018). Decreasing resources as a result of corrupt practices may have negative effects on social protection and public services as it reduces the available budget and disrupts equitable access to public services (Raišienè et al., 2019; Mazzanti et al., 2020).

Over time, corruption deepens social inequalities, reduces trust in the state, institutions, and public administration (Çera et al., 2019). Corruption can also harm income distribution and lead to the neglect of environmental protection. One of the most important aspects of corruption in the state administration is that it undermines trust in legitimate institutions, thus diminishing their ability to provide appropriate public services and to ensure a favorable environment for private sector development (Mircica, 2020). In extreme cases, corruption can lead to a failure to recognize the legitimacy of the state, causing political and economic instability (Bilan et al., 2019; Bilan et al., 2020; Grayson, 2020).

In this research, we analyze not only the phenomenon of corruption in the administrations of the EU states but also how the digitalization of the EU state administrations 
contributed in time to its continuous reduction. Our research objective is to find out how digitalization as a multidimensional phenomenon has influenced the multidimensional phenomenon of corruption in the administrations of the EU states. The results of other researchers (Fedushko et al., 2020; Anderson, 2008; Chaikin and Jason, 2009; Aidt, 2009; Billger and Goel, 2009) are completed with our findings in the EU countries by studying the interdependencies of the following variables: control of corruption; competitiveness; government effectiveness; online services index; e-government; government expenses; e-participation and others.

The paper includes an analysis of the literature, in which the concepts are presented and analyzed, based on which the main variables of the research were selected. Then the data and the research methodology are presented and the results obtained using the Canonical Correlation Analysis are analyzed. Next, the Principal Component Analysis method was applied to determine a new Correlation Index for Corruption and Digitization (CICD), calculated for each of the states included in our research. The last part of the paper contains the conclusions in which our most important and interesting contributions to the field of knowledge are highlighted.

\section{Theoretical background}

Digitalization is a necessary condition for economic and social development, for alignment with international standards, and reduced corruption (Pool, 1984; Afonasova et al., 2019; Dretske, 1982). The low degree of digitalization in the administration creates room for corruption because the relationship between digitalization and corruption is not always well enough understood (Andersen, 2009). Digitalization requires an agile government to disrupt corruption.

The first part of this section presents the concept of digitalization, in general, and in public administration, in particular, its main benefits and the implications of a low level of digitalization in society and state administrations. The second part describes the content of corruption, as it is reflected in the literature, its implications in public administration, its main determinants, and some measures to reduce corruption in administration through the digital transformation of state institutions and society.

\subsection{Digitalization and digital transformation process: Concepts and main benefits}

According to the literature, there is a diversity of opinions regarding this concept. Digitization is a driver (Russell, 2020) that contributes significantly to the modernization of societies, economies, and the transformation of state institutions (Bennett and Segerberg, 2013). Digitalization is a tool which leads to better predictability (Kliestik et al., 2020). Based on Kossow's (2020) empirical research results, digitalization creates new digital streams by using digital technologies. Digitalization is a strategy that reshapes the entire society and each organization, leading to an extensive process of digital transformation. Digitalization determines digital transformation. Digital transformation is the process of 
integrating digitalization through which society and organizations adapt to change. Digital transformation is more about adapting people to accept and use digital equipment and technology (Androniceanu, Sabie and Pegulescu, 2020). Major social, administrative, and legislative changes are taking place in the process of digital transformation. Digital transformation of the public sector has implications in all branches of society from jobs, education, health, and social security (Karpf, 2012; Gray-Hawkins and Lăzăroiu, 2020). The digital transformation of public institutions facilitates e-government.

E-government is a process of reinventing the public sector through digitalization and new information management techniques, to increase the political participation of citizens and streamline the administrative apparatus (Coursey and Norris, 2008; Ionescu, 2020). E-government manifests itself as part of the relationship between the state and society (Androniceanu, Kinnunen and Georgescu, 2020). Increasing the number of digital public services available (Ślusarczyk and Ul Haque, 2019) means lower costs for public administrations, less bureaucracy for companies and citizens, and reduced corruption. At the European level, about twenty different basic public services, such as car registration, tax returns, or registering a new company, have reached the online availability of $82 \%$ since 2010 (DeNardis, 2014). Digitalization and e-government are broadly studied issues (Androniceanu and Georgescu, 2021), but there is still no clear consensus on the factors that should be considered, when measuring e-government and how they should be grouped and quantified. Mouna, Nedra and Khaireddine (2020) show that successful e-government and digital technology adoption will lead to increased economic growth, while also working as an anti-corruption tool (Popescu, Valaskova and Majerova, 2020). Shkolnyk et al. (2020) prove that digitalization is an effective measure that has a significant contribution to eradicating corruption as a problem of state security. Mishchuk et al. (2020) find possibilities to assess losses both for the state finance system and social safety. Makowski (2017) discusses how the public authorities and public administration by their functions and digitalization can reduce the bureaucracy of public structures (Shkarlet $e t$ al., 2020).

In local public administration, digitalization and digital transformation contribute to increasing accessibility, transparency, and efficiency and reducing bureaucracy and corruption. There is a direct correlation between digitization and efficiency, both for public institutions and for other stakeholders. Even if, in the first phase, digitalization means public spending on digital investments and training of civil servants, in the medium and long term it generates efficiency by reducing public spending on bureaucracy and optimizing working time, and by improving communication and public services quality. Efficiency is represented in our research by the government effectiveness index.

Digitalization brings benefits in local public administration both for public institutions and for civil servants and other stakeholders. Some of the most important benefits are presented here. Digitization of public administration facilitates the interaction between local public administration and citizens and reduces corruption. Thus, by digitizing public services, citizens and businesses no longer come into direct contact with government officials, eliminating the context of corruption and reducing the risk of corruption. A few 
examples of such digital public services that contribute to reducing corruption in local administrations are the following: submitting documents/requests online and receiving their solution automatically; reporting problems of public interest online 24/7, even from the mobile phone (abandoned cars, potholes in asphalt, disturbing public order, obstacles on the road, garbage thrown in illegal places, lighting system failures, stray dogs, etc.); payment of taxes, fees, and fines online on the institutions' website; online verification of the status of documents submitted to the institution; real-time information on the status of submitted documents; quick access to information of public interest, automatically published on the site; citizens can automatically obtain certificates and several approvals. By digitizing public services, citizens can directly consult their land, buildings, declared cars, taxes, fines, and other taxes on the website of the institution. A remarkable example is the first virtual official in Romania named Antonia. It works in the City Hall of Cluj-Napoca. Antonia is a software that facilitates the submission and distribution to the relevant department of the mayor's office of requests from citizens or companies.

Some of the most important benefits of digitization for civil servants in the local administration are the following: saving time by finding the information sought online; online meetings; online audience appointments; total control over the entry/ exit of documents; real-time alerts on deadlines for resolving requests/documents; access from anywhere and anytime to the flow and history of a document; electronic registration and archiving; the solution supports for the implementation of the internal managerial control system; unitary record of petitions, processes, contracts, requests submitted by citizens, irregularities within the institution; planning and monitoring timesheets, holidays and others. The specific context given by the Covid 19 pandemic revealed the essential role of digitalization in public administration (Androniceanu, 2020) by offering a variety of tools through which public institutions can make significant changes to reduce corruption.

\subsection{Corruption: concept, forms, and anti-corruption measures}

A generally accepted definition of corruption is an abuse of power for personal gain (European Commission, 2020). Corruption is understood as referring to the misuse of a position in the public administration or its connections to obtain benefits for oneself or a third party (Bennett, Durana and Konecny, 2020). Beck (2021) found that countries with similar economic structures are characterized by generally lower levels of corruption. Corruption is a complex phenomenon with multiple economic, social, political, and cultural dimensions (Yousif et al., 2020; Gavurova, Kovac and Khouri, 2020). Corruption also means conflicts of interest and favoritism (Verhulst, 2002). These forms of corruption need profound structural and mental changes in public bodies and society in general, and not just through the adoption of legislation and formal compliance (Luzgina, 2017). In our opinion, corruption is a phenomenon that appears and develops in societies and public administrations where digitalization is low, bureaucracy is high, institutional transparency is weak, and internal and external communication is problematic.

Adam and Fazekas (2021) pointed out that the impact of corruption can be reduced by promoting transparency and citizen participation facilitation through ICT tools. 
Andersson (2008) studied non-OECD countries during 1996-2006 and found that corruption is determined by two time-varying factors: real GDP per capita and press freedom. Kim (2013) developed four models on 200 countries to study the interaction between e-government and anti-corruption in government. An effective policy response should be based on evidence of its spread and form in a given country, the institutional and other incentives, which favor or can be used against it. Various researchers (Androniceanu et al., 2020a; Remeikienè et al., 2020; Luzgina, 2017; Osipov, Glotov and Karepova, 2018) have analyzed which forms of corruption occur in different countries and identified highrisk sectors as well as determinants.

European Parliament has highlighted many differences between the member states in terms of crime definition, available indicators, and data recording methodology (European Parliament, 2016). Corruption may have an impact on both national and EU policies and funds (Bilan et al., 2017; European Commission, 2017). A recent study estimates the annual cost of public procurement corruption in the EU member states at $€ 5.33$ billion (European Commission, 2020). This means that corruption has become a systemic problem in European countries and requires major changes on multiple levels such as management capacity, education, monitoring and corruption control institutions (Szeiner et al., 2020), legislation, clear criteria for access to political and public positions, digitalization, transparency, and so on.

At the local level of administration, the main forms of corruption identified are related to the public funds, but also their use to favor certain private companies and a variety of illegal activities, such as bribery for the preferential allocation of subsidized housing; illicit commissions collected for awarding public contracts to preferential companies; the use by municipal officials of public goods for personal purposes; facilitating the emergency obtaining or sale of authorizations and licenses; bribery in order not to react to irregularities in construction safety, labor protection, fire safety or other violations, which can have serious social consequences; conditioning the provision of public services by paying illegal amounts; non-compliance with the provisions included in the urban planning documents of the localities and so on. These problems in some states show the correlation between competitiveness and local government corruption. Corruption reduces competitiveness between private companies that can compete to win contracts with public institutions. In countries where there is a high level of corruption in local government, competitive private companies lose contracts with public institutions precisely because they do not want to pay bribes. Preventing or reducing corruption in public institutions is significantly influenced by public managers and elected politicians. They can develop anti-corruption strategies, policies, and tools and make internal changes to control and reduce corruption.

We appreciate that there are a variety of internal and external anti-corruption measures that can be implemented in public institutions both by civil servants and politicians. For example: establishing the core values and integrity codes for effective and honest preventive conduct; elaboration of codes of conduct for civil servants as a component of the employment contract; creating internal commissions to identify the acts of corruption of officials and to prosecute them; collaboration with specialized institutions involved in the 
procedure of investigating corruption in the public institution; developing strategies for both repression and prevention of corruption and others. Public managers and politicians can block the participation of corrupt organizations in public tenders. They can organize training programs for officials to prevent acts of corruption and to know the sanctions applied for corruption. The behavior of public managers and politicians regarding digitalization and corruption significantly influences both the content of the changes determined by digitalization and the intensity of corruption in the public institutions they lead.

As it is clear from the literature, there is a close and direct link between digitization and corruption. Digitization provides the tools for improving the transparency, accessibility, efficiency, and quality of public services, as well as for reducing corruption. Our comparative analysis between EU countries using the new correlation index for corruption and digitalization demonstrates that digitalization could be a key driver for reducing corruption.

In this study, the research questions and the key hypothesis can be formulated as follows:

- RQ1: Is digitalization a success factor in reducing corruption in the EU member states during 2019-2020?

The main hypothesis is that increased digitalization is positively linked to the quality of public administration. This means that public administration would be less corrupted and more efficient and would add value through digitalization by positive implications also to competitiveness, instead of digitalizing for its own sake (Schwab and Zahidi, 2020; Mouna, Nedra and Khaireddine, 2020; Ali and Gasmi, 2017). The other hypothesis is that corruption would be higher in the administrative systems where digitalization has lower penetration.

- RQ2: What are the differences between EU countries in terms of corruption and digitalization of public administration?

To tackle the research questions, we present the data and the Canonical Correlation Analysis methodology, to study the interdependencies of the components in the digitalization set and the corruption set. Secondly, the analysis for RQ1 is conducted between the two phenomena as well as between their components in section 4 before comparing the EU countries (RQ2) using the new composite index built on all the indicators from both sets in section 5 .

\section{Research methods and data}

The methods used in this research are Canonical Correlation Analysis (CCA) and Principal Component Analysis (PCA). CCA is a statistical technique used to detect the correlations between two sets of variables (Afifi, Clark and May, 2004). The first canonical correlation has the highest importance. The correlation coefficients are significant when their absolute values are greater than 0.45. CCA was applied on the set of 27 European Union (EU) states using ten variables for 2019-2020 (Georgescu and Kinnunen, 2021; Androniceanu et al., 2020b). 
PCA is a descriptive statistical method of multidimensional factual analysis of data. PCA has been used to determine the new correlation index for corruption and digitalization (Jolliffe, 2002). Table 1 contains the ten variables selected according to their importance and relevance to reflect the corruption, digitalization, and e-government in the EU.

Table 1: The research variables

\begin{tabular}{|c|c|c|c|}
\hline Variable & Variable Label & Description of the variables & Data Sources \\
\hline $\mathrm{V}_{1}$ & Control of corruption & $\begin{array}{l}\text { The quality of governance to combat and } \\
\text { prevent corruption }\end{array}$ & theglobaleconomy.com \\
\hline $\mathrm{V}_{2}$ & Competitiveness & $\begin{array}{l}\text { The ability of a region to export more in val- } \\
\text { ue-added terms than it imports }\end{array}$ & theglobaleconomy.com \\
\hline $\mathrm{V}_{3}$ & $\begin{array}{l}\text { Regulatory quality } \\
\text { index }\end{array}$ & $\begin{array}{l}\text { The ability of government to formulate and } \\
\text { implement sound policies and regulations } \\
\text { that permit and promote private sector de- } \\
\text { velopment }\end{array}$ & theglobaleconomy.com \\
\hline $\mathrm{V}_{4}$ & $\begin{array}{l}\text { Government } \\
\text { effectiveness index }\end{array}$ & $\begin{array}{l}\text { The use by the government of information } \\
\text { technology in the public relations }\end{array}$ & theglobaleconomy.com \\
\hline $\mathrm{V}_{5}$ & Rule of law index & $\begin{array}{l}\text { The extent to which countries adhere to the } \\
\text { rule of law in practice }\end{array}$ & theglobaleconomy.com \\
\hline$V_{6}$ & E-participation & $\begin{array}{l}\text { The use of online services to facilitate the } \\
\text { interaction between government and citi- } \\
\text { zens }\end{array}$ & $\begin{array}{l}\text { UN E-Government } \\
\text { Knowledgebase }\end{array}$ \\
\hline$V_{7}$ & Online service index & $\begin{array}{l}\text { The evolution of e-government services in } \\
\text { terms of availability, quality, connectivity, } \\
\text { and diversity of channels and the use by the } \\
\text { public of these services }\end{array}$ & knoema.com \\
\hline $\mathrm{V}_{8}$ & $\begin{array}{l}\text { Human Capital Index } \\
\text { (HCl) }\end{array}$ & $\begin{array}{l}\text { How much capital each country loses } \\
\text { through lack of education and health }\end{array}$ & World Bank \\
\hline $\mathrm{V}_{9}$ & E-Government index & $\begin{array}{l}\text { Individuals using the internet with public } \\
\text { authorities (\% of individuals aged } 16 \text { to } 74 \text { ) }\end{array}$ & World Bank \\
\hline$V_{10}$ & Government expense & $\begin{array}{l}\text { Cash payments for operating activities of } \\
\text { the government in providing goods and } \\
\text { services }\end{array}$ & Eurostat \\
\hline
\end{tabular}

Source: The authors

In Table 1, the corruption indicators $\left(\mathrm{V}_{1}-\mathrm{V}_{5}\right)$ represent the dependent set and the digitalization indicators $\left(\mathrm{V}_{6}-\mathrm{V}_{10}\right)$ represent the independent set. Five dependent variables are predicted: $\mathrm{V}_{1}-\mathrm{V}_{5}$, based on five independent variables: $\mathrm{V}_{6}-\mathrm{V}_{10}$. In our approach, the ten variables are grouped into three sub-indicators: $(1)$ variables related to the content $\left(\mathrm{V}_{2}\right.$, $\left.\mathrm{V}_{3}, \mathrm{~V}_{5}\right) ;(2)$ variables describing the analyzed phenomenon $\left(\mathrm{V}_{1}, \mathrm{~V}_{6}, \mathrm{~V}_{7}, \mathrm{~V}_{9}, \mathrm{~V}_{10}\right)$ and (3) variables reflecting the impact of phenomenon $\left(\mathrm{V}_{4}, \mathrm{~V}_{8}\right)$. Section 4 will conduct the CCA accompanied by regression analysis and section 5 will construct the composite index. 


\section{Results based on the Canonical Correlation Analysis}

Figure 1 describes the distributions of corruption indicators and their correlation. The within-set correlations of corruption variables $\mathrm{V}_{1}-\mathrm{V}_{5}$ are very high, all significant at a $1 \%$ level ranging from 0.84 to 0.95 .

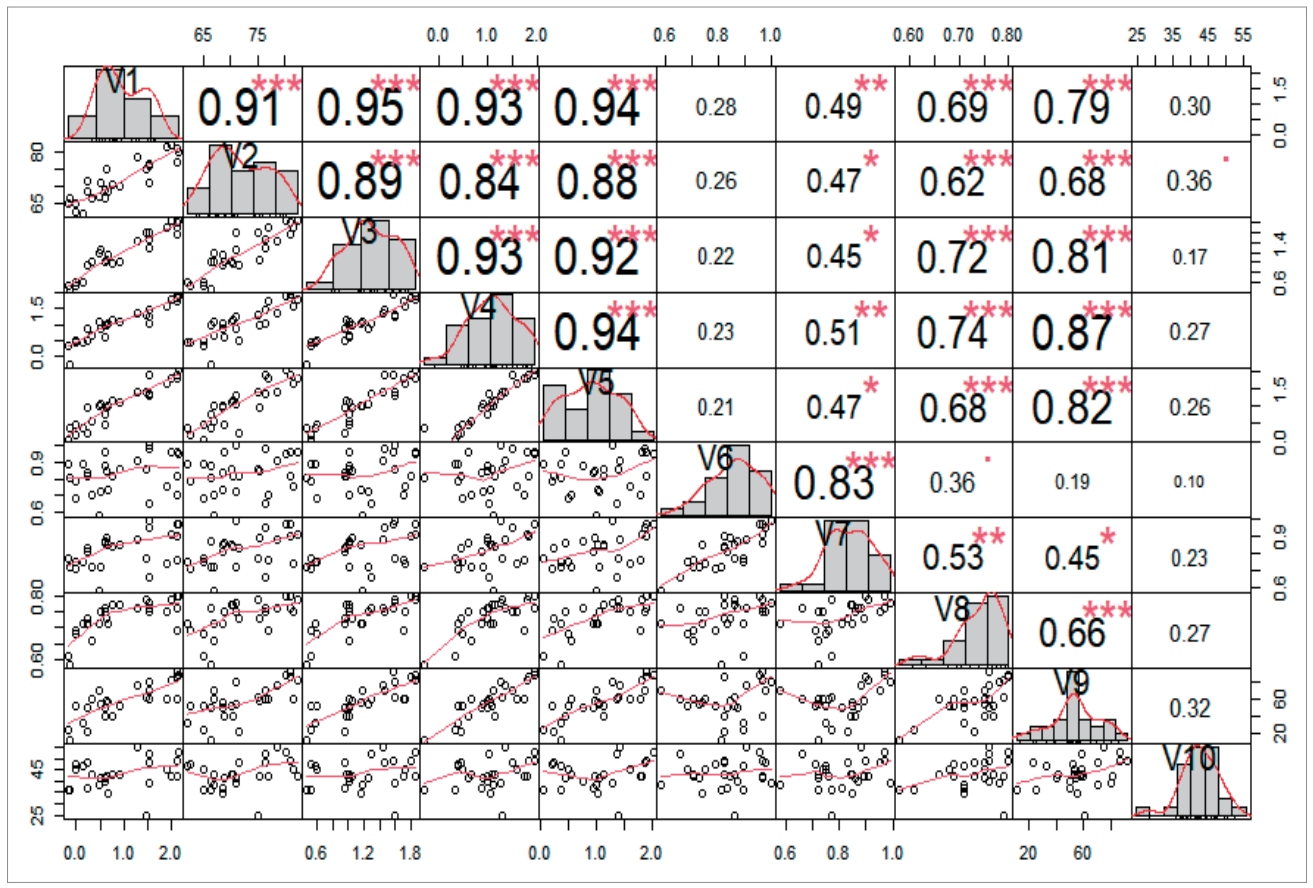

Figure 1: Set 1 (Corruption) and Set 2 (Digitalization)

Source: Authors' research

The within-set statistically significant correlations of digitalization variables $\mathrm{V}_{6}-\mathrm{V}_{10}$ range from 0.45 between $\mathrm{V}_{7}$ and $\mathrm{V}_{9}$ to 0.83 between $\mathrm{V}_{6}$ and $\mathrm{V}_{7}$; other significant correlations are between $\mathrm{V}_{7}$ and $\mathrm{V}_{8}$ at 0.53 , and between $\mathrm{V}_{8}$ and $\mathrm{V}_{9}$ at 0.66 . We note that $\mathrm{V}_{10}$ does not correlate statistically significantly with any variable within nor between sets at the $5 \%$ level. $\mathrm{V}_{6}$ does not correlate significantly with any variable of the correlation set. $\mathrm{V}_{7}$ correlates between 0.45 and 0.51 with corruption indicators; $\mathrm{V}_{8}$ between 0.62 and 0.74 ; E-government $\mathrm{V}_{9}$, between 0.79 and 0.87 (with $\mathrm{V}_{4}$ ), the highest seen correlation.

Table 2 contains the first canonical correlation which is 0.92062 . Then, $89.01 \%$ of the variation in $A_{1}$ is explained by the variation in $B_{1}$.

Table 2: Eigenvalues and canonical correlations

\begin{tabular}{cccccc}
\hline Root No. & Eigenvalue & Pct. & Cum. Pct. & Canon Cor. & Sq. Cor \\
\hline 1 & 5.55939 & 89.01701 & 89.01701 & 0.92062 & 0.84755 \\
\hline
\end{tabular}

Source: Authors' research 
The first canonical variable for corruption is:

$$
\mathrm{A} 1=0.57741 \mathrm{~V}_{1}+0.05942 \mathrm{~V}_{2}-1.50744 \mathrm{~V}_{3}-1.63842 \mathrm{~V}_{4}-0.33851 \mathrm{~V}_{5}
$$

The first canonical variable for digitalization is:

$$
\mathrm{B} 1=2.14115 \mathrm{~V}_{6}-2.16536 \mathrm{~V}_{7}-6.15738 \mathrm{~V}_{8}-0.03689 \mathrm{~V}_{9}+0.02873 \mathrm{~V}_{10}
$$

The relative contribution of each covariate to each canonical variable is reported in Table 3.

Table 3: Correlations between covariates and canonical variables

\begin{tabular}{cccccc}
\hline Covariate & $\mathbf{1}$ & $\mathbf{2}$ & $\mathbf{3}$ & $\mathbf{4}$ & $\mathbf{5}$ \\
\hline $\mathbf{V}_{6}$ & -0.18902 & -0.43740 & 0.56578 & 0.05796 & 0.67044 \\
$\mathbf{V}_{\mathbf{7}}$ & -0.49213 & -0.49361 & 0.12522 & -0.15360 & 0.68912 \\
$\mathbf{V}_{8}$ & -0.80292 & -0.16951 & 0.38433 & -0.41311 & -0.09059 \\
$\mathbf{V}_{9}$ & -0.95085 & -0.14489 & -0.05675 & 0.26198 & -0.05503 \\
$\mathbf{V}_{10}$ & -0.15955 & -0.89640 & -0.09458 & 0.03366 & -0.40125 \\
\hline
\end{tabular}

Source: Authors' research

The first canonical variable for digitalization (Table 3) is negatively strongly dominated by $\mathrm{V}_{9}$ (E-government) with a correlation coefficient of -0.95085 , followed by $\mathrm{V}_{8}(\mathrm{HCI})$ with -0.80292 . The second canonical variable for digitalization is negatively strongly dominated by $\mathrm{V}_{10}$ (Government expense) with -0.89640 . The third canonical variable is moderately dominated by $\mathrm{V}_{6}$ (E-participation) with 0.56578 . Table 4 contains the variance in covariates based on canonical variables considered. In Table 4, 31.39\% of the variance among the covariate set digitalization is explained by the first dependent canonical variate, while $37.04 \%$ of the variance is explained by the first covariate canonical variate.

Table 4: Variance in covariates explained by canonical variables

\begin{tabular}{ccrrc}
\hline CAN. VAR. & Pct Var DEP & Cum Pct DEP & Pct Var COV & Cum Pct COV \\
\hline $\mathbf{1}$ & 31.39622 & 31.39622 & 37.04364 & 37.04364 \\
$\mathbf{2}$ & 9.23444 & 40.63066 & 25.76442 & 62.80806 \\
\hline
\end{tabular}

Source: Authors' research

Similarly, 9.23\% of the variance among digitalization is explained by the second dependent canonical variate, while $25.76 \%$ is explained by the second covariate canonical variate. Table 5 briefly reports the regression analysis results of the effect of the most important and statistically significant digitalization indicators on each corruption indicator; Beta measures the importance of each covariate. 
Table 5: Regression analysis for the cells error term

\begin{tabular}{|c|c|c|c|c|c|c|c|}
\hline Covariate & B & Beta & Std. Err. & $\mathrm{t}$-Value & Sig. of $\mathrm{t}$ & Lower-95\% & CL-Upper \\
\hline \multicolumn{8}{|c|}{ Dependent variable: Control of corruption $\left(\mathrm{V}_{1}\right)$} \\
\hline $\mathbf{V}_{9}$ & 0.0221 & 0.5580 & 0.0071 & 3.0760 & 0.006 & 0.0071 & 0.0370 \\
\hline \multicolumn{8}{|c|}{ Dependent variable: Competitiveness $\left(\mathrm{V}_{2}\right)$} \\
\hline$V_{9}$ & 0.1268 & 0.4025 & 0.0679 & 1.8660 & 0.076 & -0.0145 & 0.2681 \\
\hline \multicolumn{8}{|c|}{ Dependent variable: Regulatory quality index $\left(\mathrm{V}_{3}\right)$} \\
\hline $\mathrm{V}_{8}$ & 2.7269 & 0.3438 & 1.2807 & 2.1291 & 0.045 & 0.0634 & 5.3904 \\
\hline $\mathbf{V}_{9}$ & 0.0128 & 0.5914 & 0.0036 & 3.5701 & 0.002 & 0.0053 & 0.0203 \\
\hline \multicolumn{8}{|c|}{ Dependent variable: Government effectiveness $\left(\mathrm{V}_{4}\right)$} \\
\hline $\mathrm{V}_{8}$ & 2.8450 & 0.2780 & 1.3584 & 2.0943 & 0.049 & 0.0200 & 5.6701 \\
\hline$V_{9}$ & 0.0174 & 0.6234 & 0.0038 & 4.5773 & 0.000 & 0.0095 & 0.0254 \\
\hline \multicolumn{8}{|c|}{ Dependent variable: Rule of law index $\left(\mathrm{V}_{5}\right)$} \\
\hline $\mathbf{V}_{9}$ & 0.0185 & 0.6176 & 0.0051 & 6.6252 & 0.002 & 0.0079 & 0.0292 \\
\hline
\end{tabular}

Source: Authors' research

According to Table 5, the main findings of the analyses are the following:

- The effect of $\mathrm{V}_{9}$ E-government is the most important when predicting $\mathrm{V}_{1}$ Control of corruption;

- The effect of $\mathrm{V}_{9}$ E-government is the most important when predicting $\mathrm{V}_{2}$ competitiveness;

- The effect of $V_{9}$ E-government is more important than the effect of $V_{8}$ HCI when predicting the $\mathrm{V}_{3}$ Regulatory quality index;

- The effect of $V_{9}$ E-government is more important than the effect of $V_{8}$ HCI when predicting $\mathrm{V}_{4}$ Government effectiveness;

- The effect of $\mathrm{V}_{9}$ E-government is the most important when predicting $\mathrm{V}_{5}$ Rule of law index;

These results validate the second hypothesis, according to which an increased digitalization of the public institutions is positively linked to the quality of public administration and reduced corruption.

\section{The new correlation index of corruption and digitalization}

To build the correlation index based on the ten variables, we applied Principal Component Analysis (PCA) and identified principal components (PC). PC1 explains 64.90\% of the original variance and the first two PCs explain together $79.68 \%$. Thus, we will retain only the first two PCs. Table 6 shows the component matrix with loadings, rotated by Varimax rotation. We considered only loadings $>0.5$. 
Table 6. Rotated component matrix

\begin{tabular}{ccccccccccc}
\hline & $\mathrm{V}_{1}$ & $\mathrm{~V}_{2}$ & $\mathrm{~V}_{3}$ & $\mathrm{~V}_{4}$ & $\mathrm{~V}_{5}$ & $\mathrm{~V}_{6}$ & $\mathrm{~V}_{7}$ & $\mathrm{~V}_{8}$ & $\mathrm{~V}_{9}$ & $\mathrm{~V}_{10}$ \\
\hline PC1 & 0.946 & 0.890 & 0.952 & 0.955 & 0.955 & 0.063 & 0.345 & 0.719 & 0.863 & 0.320 \\
PC2 & 0.197 & 0.191 & 0.138 & 0.185 & 0.138 & 0.965 & 0.896 & 0.366 & 0.152 & 0.160 \\
\hline
\end{tabular}

Source: Authors' research

PC1 is dominated by Set 1 of the corruption indicators $V_{1}-V_{5}$, but it contains also digitalization variables $\mathrm{V}_{8}$ (HCI related to expected education and health of new-born citizens, which will determine future productivity) and $\mathrm{V}_{9}$ (E-government measuring the broadness of the dealings between government agencies and citizens, which can be handled digitally online). PC2 is determined only by $\mathrm{V}_{6}$ (E-participation referring to ICT-supported participation of citizens with government agencies in e-government-related processes, e.g. such as government services, administration, and policymaking) and $\mathrm{V}_{7}$ (Online service index measuring the evolution of e-government services by their quality and availability to citizens). Government expenditure, $\mathrm{V}_{10}$ including public consumption and investments as well as income and capital transfers, has loading $<0.5$ and it will not be a factor in either retained PC as it does not carry information explaining the variation in corruption and digitalization.

Based on the two retained PCs and the coefficients in Table 6, the first two PCs become:

$$
\begin{aligned}
& \mathrm{PC} 1=0.946 \mathrm{~V}_{1}+0.890 \mathrm{~V}_{2}+0.952 \mathrm{~V}_{3}+0.955 \mathrm{~V}_{4}+0.955 \mathrm{~V}_{5}+0.719 \mathrm{~V}_{8}+0.863 \mathrm{~V}_{9} \\
& \mathrm{PC} 2=0.965 \mathrm{~V}_{6}+0.896 \mathrm{~V}_{7}
\end{aligned}
$$

To compute the composite index, which we call the Correlation Index of Corruption and Digitalization (CICD), the PCs are weighted by the ratio of the percentage of how much a PC explains of the total cumulative variation of the retained PCs, i.e.

$$
\text { CFDI }=(64.903 / 79.681) * \mathrm{PC} 1+(14.777 / 79.681) * \mathrm{PC} 2 .
$$

This gives us the following equation:

$$
\begin{aligned}
\mathrm{CICD}= & 0.771 \mathrm{~V}_{1}+0.725 \mathrm{~V}_{2}+0.775 \mathrm{~V}_{3}+0.778 \mathrm{~V}_{4}+0.778 \mathrm{~V}_{5}+ \\
& 0.586 \mathrm{~V}_{8}+0.703 \mathrm{~V}_{9}+0.179 \mathrm{~V}_{6}+0.166 \mathrm{~V}_{7}
\end{aligned}
$$

Using the original data for $\mathrm{V}_{1}-\mathrm{V}_{10}$, we compute $C I C D$ values for each European Union country, as can be seen in Figure 2 .

The index values are finally scaled between 0 and 100 by Min-Max normalization. Figure 2 visualizes the ordered CICD values for EU countries. Nordic countries show the greatest values suggesting that they are digitalized and the most effective in terms of lack of corruption, Finland achieving the largest $\mathrm{CICD}=100.0$, while Bulgaria $(\mathrm{CICD}=8.0)$ and Romania $(\mathrm{CICD}=0.0)$ are the least digitalized with relatively high corruption indicators. Romania has the smallest values for $\mathrm{V}_{8}$ (Human capital index) and $\mathrm{V}_{9}$ (E-government) as well as for $\mathrm{V}_{3}$ (Regulatory quality index) and $\mathrm{V}_{4}$ (Government effectiveness). Bulgaria also has very low values for digitalization and the lowest values of the $E U$ states for $V_{1}$ 


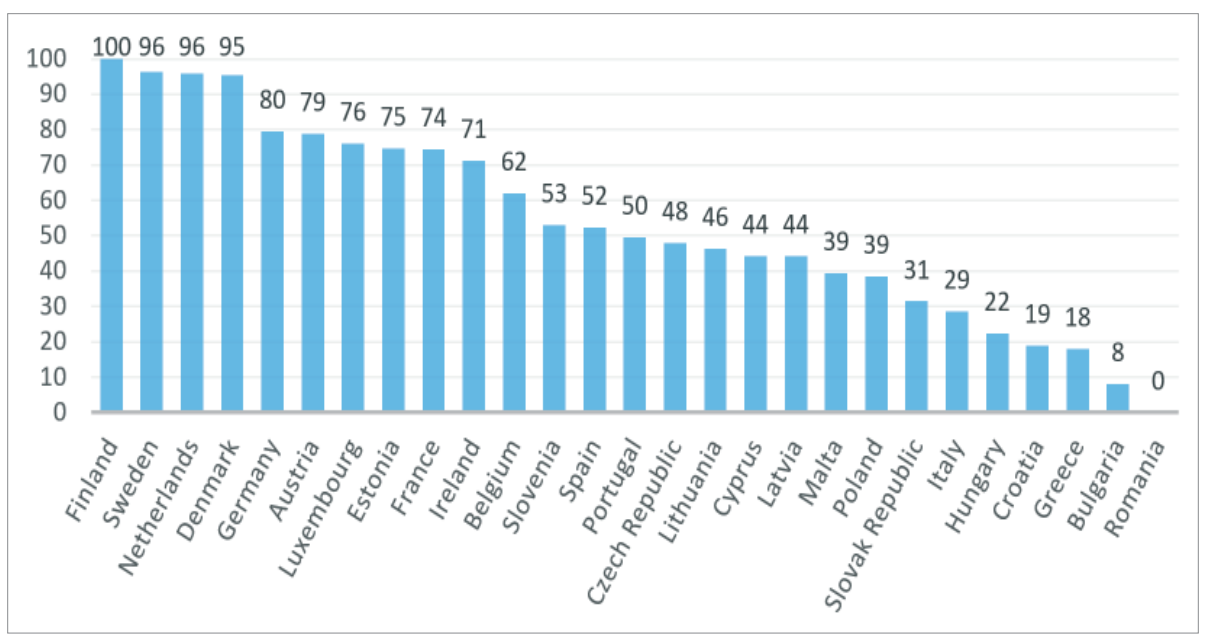

Figure 2: Correlation Index of Corruption and Digitalization (CICD) in the EU member states

Source: Authors' research

(Control of corruption) and $\mathrm{V}_{5}$ (Rule of law index). These results answer the two research questions, as they confirm the differences between EU member states, both in terms of the degree of digitization associated with corruption, but also the fact that digitization, in the states investing in it, is a success factor in the fight against corruption. The results show that corruption was persistent in Europe amid the Covid-19 pandemic during 2019-2020. This was also confirmed by Transparency International, with the launch of the report on the Corruption Perceptions Index in 2020 (Transparency International, 2020). The results of our research show that the place recorded in the Corruption Perceptions Index (CPI) in 2020 is linked to how a country meets the challenges posed by the pandemic. States with a good ranking seem to invest more in the healthcare system and are less likely to violate democratic and institutional rules or the rule of law.

\section{Conclusions}

The future of society, democracy, and government are digital. The digitization of public service is a strategic objective. The results of our research have direct implications for the policies and reforms in the administrations of European states. Comparisons between states through our proposed index show that digitizing the administration is one of the most effective ways to reduce corruption in the public sector. This conclusion underlines the fact that state administrations should design and implement appropriate strategies and policies for the integration of large-scale digital applications. Our research results are proving the fact that the digital transformation of public administration in the EU states continues to be influenced by a lot of factors: technological, economic, administrative, managerial-strategic, educational, and political. Beyond efficiency, digitalization of public service and administration sends a strong signal at the local and international level on the 
determination of policymakers to move into an era of transparency and the fight against corruption (Sieja and Wach, 2019). The countries that do not prioritize the cross-cutting integration of technology at all levels of the economy and society will lose important opportunities and will suffer.

The results of this study showed a canonical correlation of $89.02 \%$, confirming RQ1 that the greater the digitalization is, the greater the quality of public administration is. E-government was the best predictor of control of corruption and competitiveness suggesting that the digitalized, less corrupt governments, also made economies more competitive. The comparison of countries (RQ2) was done by introducing the new index CICD as a real tool for an effective comparative analysis. The Nordic countries showed the best performance as relatively corruption-free digitalized states, while the greatest challenges were seen in Bulgaria and Romania.

During the analyzed period, we noticed three important changes in the EU: the accelerated and massive digital penetration in state administration, the significant reduction of corruption in EU states as a result of digitalization, and the increase of the degree of accessibility of institutions from the administrations of European states because of increased digitalization. By digitizing the administration and reducing corruption in public institutions, EU states are moving towards a digital society and economy. As presented in this paper, digitalization brings with it new forms of organization, new managerial models and types of institutional processes, new social mechanisms, new instruments for making reforms in public administration, new leadership as well as a new type of values for society.

\section{References:}

1. Adam, I. and Fazekas, M., 'Are Emerging Technologies Helping Win the Fight Against Corruption? A Review of the State of Evidence', 2021, Information Economics and Policy, vol. 57, pp. $1-14$.

2. Afifi, A., Clark, V. and May, S., Computer-Aided Multivariate Analysis, Boca Raton: Chapman and Hall/CRC, 2004.

3. Afonasova, M.A., Panfilova, E.E., Galichkina, M.A. and Ślusarczyk, B., 'Digitalization in Economy and Innovation: The Effect on Social and Economic Processes', 2019, Polish Journal of Management Studies, vol. 19, no. 2, pp. 22-32.

4. Aidt, T.S., 'Corruption, Institutions, and Economic Development', 2009, Oxford Review of Economic Policy, vol. 25, pp. 271-291.

5. Ali, M.S.B. and Gasmi, A., 'Does ICT Diffusion Matter for Corruption? An Economic Development Perspective', 2017, Telematics and Informatics, vol. 34, no. 8, pp. 1445-1453.

6. Andersen, T.B., 'E-Government as an Anti-Corruption Strategy', 2009, Information Economics and Policy, vol. 21, no. 3, pp. 201-210.

7. Andersson, S., 'Studying the Risk of Corruption in the Least Corrupt Countries', 2008, Public Integrity, vol. 10, no. 3, pp. 193-214.

8. Androniceanu, A., Sabie, O.M. and Pegulescu, A., 'An Integrated Approach of the Human Resources Motivation and the Quality of Health Services', 2020, Theoretical and Empirical Research in Urban Management, vol. 15, no.1, pp. 42-53. 
9. Androniceanu, A. and Georgescu, I., 'E-Government in European Countries, a Comparative Approach Using the Principal Components Analysis', 2021, NISPAcee Journal of Public Administration and Policy, vol. 14, no. 2, pp. 65-86.

10. Androniceanu, A., 'Major Structural Changes in the EU Policies Due to the Problems and Risks Caused by COVID-19', 2020, Administrație și Management Public, vol. 34, pp. 137-149.

11. Androniceanu, A., Kinnunen, J. and Georgescu, I., 'E-Government Clusters in the EU based on the Gaussian Mixture Models', 2020, Administratie si Management Public, vol. 35, pp. 6-20.

12. Androniceanu, A.M., Georgescu, I., Tvaronavičiene, M. and Androniceanu, A., 'Canonical Correlation Analysis and A New Composite Index on Digitalization and Labor Force in the Context of the Industrial Revolution 4.0', 2020b, Sustainability, vol. 12, no. 17, article no. 6812.

13. Androniceanu, A.M., Kinnunen, J., Georgescu, I. and Androniceanu, A., 'A Multidimensional Approach to Competitiveness, Innovation and Well-Being in the EU using Canonical Correlation Analysis', 2020a, Journal of Competitiveness, vol. 12, no. 4, pp. 5-21.

14. Balzer, R., Užík, M. and Glova, J., 'Managing Growth Opportunities in the Digital Era - An Empiric Perspective of Value Creation', 2020, Polish Journal of Management Studies, vol. 21, no. 2, pp. 87-100.

15. Beck, K., 'Drivers of Structural Convergence: Accounting for Model Uncertainty and Reverse Causality', 2021, Entrepreneurial Business and Economics Review, vol. 9, no. 1, pp. 189-208.

16. Bennett, T.J., Durana, P. and Konecny, V., 'Urban Internet of Things Systems and Interconnected Sensor Networks in Sustainable Smart City Governance', 2020, Geopolitics, History, and International Relations, vol. 12, no. 2, pp. 51-57.

17. Bennett, W.L. and Segerberg, A., The Logic of Connective Action: Digital Media and the Personalization of Contentious Politics, Cambridge: Cambridge University Press, 2013.

18. Bilan, Y., Gavurova, B., Stanislaw, G. and Tkacova, A., 'The Composite Coincident Indicator (CCI) for Business Cycles', 2017, Acta Polytechnica Hungarica, vol. 14, no. 7, pp. 71-90.

19. Bilan, Y., Hussain, H.I., Haseeb, M. and Kot, S., 'Sustainability and Economic Performance: Role of Organizational Learning and Innovation', 2020, Engineering Economics, vol. 31, no. 1, pp. 93-103.

20. Bilan, Y., Mishchuk, H., Samoliuk, N. and Grishnova, O., 'ICT and Economic Growth: Links and Possibilities of Engaging', 2019, Intellectual Economics, vol. 13, no. 1, pp. 1-12.

21. Billger, S.M. and Goel, R K., 'Do Existing Corruption Levels Matter in Controlling Corruption? Cross-Country Quantile Regression Estimates', 2009, Journal of Development Economics, vol. 90, pp. 299-305.

22. Çera, G., Meço, M., Çera, E. and Maloku, S., 'The Effect of Institutional Constraints and Business Network on Trust in Government: An Institutional Perspective’, 2019, Administrație și Management Public, vol. 33, pp. 6-19.

23. Chaikin, D. and Jason, S., Corruption and Money Laundering: A Symbiotic Relationship, New York: Springer, 2009.

24. Coursey, D. and Norris, D.F., 'Models of E-Government: Are They Correct? An Empirical Assessment', 2008, Public Administration Review, vol. 68, no. 3, pp. 523-536.

25. DeNardis, L., The Global War for Internet Governance, New Haven: Yale University Press, 2014.

26. Dretske, F., Knowledge and the Flow of Information, Cambridge: MIT Press, 1982. 
27. European Commission, 'European Semester: Thematic Factsheet - Public Procurement', 2017, [Online] available at https://ec.europa.eu/info/sites/info/files/file_import/european-se mester_thematic-factsheet_public-procur ement_en_0.pdf, accessed on January 10, 2021.

28. European Commission, 'The Corruption Perception Index 2019: The EU is the Best Performer in the World', 2020, [Online] available at https://ec.europa.eu/regional_policy/en/newsroom/ news/2020/01/27-01-2020-the-corruption-perception-index-2019-the-eu-is-the-best-perform er-in-the-world, accessed on March 6, 2021.

29. European Parliament, 'The Cost of Non- Europe in the Area of Organised Crime and Corruption', 2016, [Online] available at https://www.europarl.europa.eu/RegData/etudes/ STUD/2016/579319/EPRSSTU (2016)57 9319_EN.pdf, accessed on March 16, 2021.

30. Fedushko, S., Mastykash, O., Syerov, Y. and Peracek, T., 'Model of User Data Analysis Complex for the Management of Diverse Web Projects during Crises', 2020, Applied Sciences, vol. 10, no. 24, pp. 1-12, article no. 9122.

31. Gavurova, B., Kovac, V. and Khouri, S., 'Purpose of Patient Satisfaction for Efficient Management of Healthcare Provision', 2020, Polish Journal of Management Studies, vol. 22, no. 1, pp. $134-146$.

32. Georgescu, I. and Kinnunen, J., 'The Digital Effectiveness on Economic Inequality: A Computational Approach', in Dima, A.M. and D’Ascenzo, F. (eds.), Business Revolution in a Digital Era, Springer Proceedings in Business and Economics, Springer, 2021.

33. Gray-Hawkins, M. and Lăzăroiu, G., 'Industrial Artificial Intelligence, Sustainable Product Lifecycle Management, and Internet of Things Sensing Networks in Cyber-Physical Smart Manufacturing Systems', 2020, Journal of Self-Governance and Management Economics, vol. 8, no. 4, pp. 19-28.

34. Grayson, J., 'Big Data Analytics and Sustainable Urbanism in Internet of Things-Enabled Smart Governance', 2020, Geopolitics. History, and International Relations, vol. 12, no. 2, pp. 23-29.

35. Ionescu, L., 'Digital Data Aggregation, Analysis, and Infrastructures in Fin Tech Operations', 2020, Review of Contemporary Philosophy, vol. 19, pp. 92-98.

36. Jolliffe, I.T., Principal Component Analysis, New York: Springer, 2002.

37. Karpf, D., The MoveOn Effect: The Unexpected Transformation of American Political Advocacy, Oxford : Oxford University Press, 2012.

38. Kim, C.K., 'Anti-Corruption Initiatives and E-Government: A Cross-National Study', 2013, Public Organization Review, vol. 14, no. 3, pp. 385-396.

39. Kliestik, T., Nica, E., Musa, H., Poliak, M. and Mihai, E.A., 'Networked, Smart, and Responsive Devices in Industry 4.0 Manufacturing Systems', 2020, Economics, Management, and Financial Markets, vol. 15, no. 3, pp. 23-29.

40. Kossow, N., 'Digitizing Collective Action: How Digital Technologies Support Civil Society's Struggle against Corruption', Doctoral Dissertation, Berlin, 2020, [Online] available at https:// opus4.kobv.de/opus4-hsog/frontdoor/deliver/index/docId/3702/file/Dissertation_Kossow. pdf, accessed on September 25, 2021.

41. Luzgina, A., 'Problems of Corruption and Tax Evasion in Construction Sector in Belarus', 2017, Entrepreneurship and Sustainability Issues, vol. 5, no. 2, pp. 263-282.

42. Makowski, G., 'From Weber to the Web... Can ICT Reduce Bureaucratic Corruption?', in Paulin, A., Anthopoulos, L. and Reddick, C. (eds.), Beyond Bureaucracy. Public Administration and Information Technology, New York: Springer, 2017. 
43. Mansell, R., Imagining the Internet: Communication, Innovation, and Governance, Oxford: Oxford University Press, 2012.

44. Mazzanti, M., Mazzarano, M., Pronti, A. and Quatrosi, M., 'Fiscal Policies, Public Investments and Wellbeing: Mapping the Evolution of the EU', 2020, Insights into Regional Development, vol. 2, no. 4, pp. 725-749.

45. Mircica, N., 'Restoring Public Trust in Digital Platform Operations: Machine Learning Algorithmic Structuring of Social Media Content', 2020, Review of Contemporary Philosophy, vol. 19, pp. 85-91.

46. Mishchuk, H., Bilan, S., Yurchyk, H., Akimova, L. and Navickas, M., 'Impact of the Shadow Economy on Social Safety: The Experience of Ukraine', 2020, Economics and Sociology, vol. 13, no. 2, pp. 284-298.

47. Mouna, A., Nedra, B. and Khaireddine, M., 'International Comparative Evidence of E-Government Success and Economic Growth: Technology Adoption as an Anti-Corruption Tool', 2020, Transforming Government: People, Process and Policy, vol. 14, no. 5, pp. 713-736.

48. Osipov, G.V., Glotov, V.I. and Karepova, S.G., 'Population in the Shadow Market: Petty Corruption and Unpaid Taxes', 2018, Entrepreneurship and Sustainability Issues, vol. 6, no. 2, pp. 692-710.

49. Pool, I. de S., Technologies of Freedom, Cambridge: Harvard University Press, 1984.

50. Popescu, G.H., Valaskova, K. and Majerova, J., 'Real-Time Sensor Networks, Advanced Robotics, and Product Decision-Making Information Systems in Data-Driven Sustainable Smart Manufacturing', 2020, Economics, Management, and Financial Markets, vol. 15, no. 4, pp. 29-38.

51. Raišienè, A.G., Bilan, S., Smalskys, V. and Gečienė, J., 'Emerging Changes in Attitudes to Inter-Institutional Collaboration: The Case of Organizations Providing Social Services in Communities', 2019, Administrație și Management Public, vol. 33, pp. 34-56.

52. Remeikienė, R., Gasparènienė, L., Chadyšas, V. and Raistenskis, E., 'Links Between Corruption and Quality of Life in European Union', 2020, Entrepreneurship and Sustainability Issues, vol. 7, no. 4, pp. 2664-2675.

53. Russell, H., 'Sustainable Urban Governance Networks: Data-Driven Planning Technologies and Smart City Software Systems', 2020, Geopolitics, History, and International Relations, vol. 12, no. 2, pp. 9-15.

54. Rymarczyk, J., 'The Impact of Industrial Revolution 4.0 on International Trade', 2021, Entrepreneurial Business and Economics Review, vol. 9, no. 1, pp. 105-117.

55. Şandor, S.D., 'Measuring Public Sector Innovation', 2018, Transylvanian Review of Administrative Sciences, no. 54E, pp. 125-137.

56. Schwab, K. and Zahidi, S., The Global Competitiveness Report, Geneva: The World Economic Forum, 2020.

57. Shkarlet, S., Oliychenko, I., Dubyna, M., Ditkovska, M. and Zhovtok, V., 'Comparative Analysis of Best Practices in E-Government Implementation and Use of This Experience by Developing Countries', 2020, Administrație şi Management Public, vol. 34, pp. 118-136.

58. Shkolnyk, I., Kozmenko, S., Polach, J. and Wolanin, E., 'State Financial Security: Comprehensive Analysis of Its Impact Factors', 2020, Journal of International Studies, vol. 13, no. 2, pp. 291-309. 
59. Sieja, M. and Wach, K., 'The Use of Evolutionary Algorithms for Optimization in the Modern Entrepreneurial Economy: Interdisciplinary Perspective', 2019, Entrepreneurial Business and Economics Review, vol. 7, no. 4, pp. 117-130.

60. Ślusarczyk, B. and Ul Haque, A., 'Public Services for Business Environment: Challenges for Implementing Industry 4.0 in Polish and Canadian Logistic Enterprises', 2019, Administrație și Management Public, vol. 33, pp. 57-76.

61. Szeiner, Z., Mura, L., Horbulák, Z., Roberson, M. and Poor, J., 'Management Consulting Trends in Slovakia in the Light of Global and Regional Tendencies', 2020, Journal of Eastern European and Central Asian Research, vol. 7, no. 2, pp. 191-204.

62. Transparency International, 'Annual Report 2020', [Online] available at https://images.trans parencycdn.org/images/TI_AnnualReport2020_v10@72ppi.pdf, accessed on January 7, 2022.

63. Verhulst, S., 'About Scarcities and Intermediaries: The Regulatory Paradigm Shift of Digital Content Reviewed', in Lievrouw, L.A. and Livingstone, S. (eds.), The Handbook of New Media, London: Sage Publications, 2002, pp. 432-447.

64. Vogelsang, M., Digitalization in Open Economies: Theory and Policy Implications, New York: Springer, 2010.

65. Winston, B., Media, Technology, and Society: A History: From the Telegraph to the Internet, London: Psychology Press, 1998.

66. Yousif, N.B.A., Grondys, K., Gad, S. and Elsayed, W., 'Knowledge Management in Non-Governmental Organizations (NGOs)', 2020, Administrație și Management Public, vol. 35, pp. 90-108. 